University of Wollongong

Research Online

Faculty of Social Sciences - Papers (Archive) Faculty of Arts, Social Sciences \& Humanities

2015

Participatory action research: The distress of (not) making a difference

Natascha Klocker

University of Wollongong, natascha@uow.edu.au

Follow this and additional works at: https://ro.uow.edu.au/sspapers

Part of the Education Commons, and the Social and Behavioral Sciences Commons

Research Online is the open access institutional repository for the University of Wollongong. For further information contact the UOW Library: research-pubs@uow.edu.au 


\title{
Participatory action research: The distress of (not) making a difference
}

\author{
Abstract \\ Participatory action research (PAR) is alluring for researchers investigating traumatic and sensitive \\ topics. While it is distressing for interviewees to recount these stories - and for researchers to hear them - \\ PAR promises to make the pain worthwhile. Something good will come of it. In this paper, I reflect on a \\ PAR project conducted with Tanzanian child domestic workers. Research vignettes are used to highlight \\ moments of emotional complexity unique to PAR projects. First, the emotional burdens of PAR are \\ distributed across a research team. Researchers need to think carefully about the appropriate 'level' of \\ participation to pursue. Second, there is no guarantee that the impacts of PAR projects will be \\ unambiguously positive. The risk of doing more harm than good can weigh heavily on the minds of the \\ research team. Third, when PAR projects are conceived with the intent of producing long-lasting structural \\ changes that benefit marginalised people, 'failure' can become a source of great distress. Those \\ attempting PAR need to be prepared for the emotional pitfalls of research endeavours that seek to \\ tangibly intervene in traumatised people's lives.
}

\section{Keywords}

difference, action, participatory, research, distress, not, making

Disciplines

Education | Social and Behavioral Sciences

\section{Publication Details}

Klocker, N. (2015). Participatory action research: The distress of (not) making a difference. Emotion, Space and Society, 17 37-44. 
Participatory Action Research: the distress of (not) making a difference

Dr Natascha Klocker

Senior Lecturer

Australian Centre for Cultural Environmental Research

Department of Geography and Sustainable Communities

Faculty of Social Sciences

University of Wollongong NSW 2522

Australia

Email: natascha_klocker@uow.edu.au

Phone: (+612) 42981331

\section{Acknowledgements}

The research upon which this article is based was conducted with the participation of Esther John Malifedha, Paul Mbenna, Faidha Mlossi, Vaileth Mvena and Amina Haule. Their contributions were substantial and are duly acknowledged here. The author would also like to thank Professors Kevin Dunn and Chris Gibson for their guidance over the duration of the research project and Danielle Drozdzewski, Dale Dominey-Howes and the three anonymous reviewers for their thoughtful comments on the manuscript. 


\title{
Participatory Action Research: the distress of (not) making a difference
}

\begin{abstract}
Participatory action research (PAR) is alluring for researchers investigating traumatic and sensitive topics. While it is distressing for interviewees to recount these stories - and for researchers to hear them - PAR promises to make the pain worthwhile. Something good will come of it. In this paper, I reflect on a PAR project conducted with Tanzanian child domestic workers. Research vignettes are used to highlight moments of emotional complexity unique to PAR projects. First, the emotional burdens of PAR are distributed across a research team. Researchers need to think carefully about the appropriate 'level' of participation to pursue. Second, there is no guarantee that the impacts of PAR projects will be unambiguously positive. The risk of doing more harm than good can weigh heavily on the minds of the research team. Third, when PAR projects are conceived with the intent of producing longlasting structural changes that benefit marginalised people, 'failure' can become a source of great distress. Those attempting PAR need to be prepared for the emotional pitfalls of research endeavours that seek to tangibly intervene in traumatised people’s lives.
\end{abstract}

Keywords: participatory action research, trauma, ethics, young people, children, emotion 


\section{Introduction}

Participatory Action Research (PAR) foregrounds both action and participation. Action is central to PAR because it seeks to make tangible, positive changes to the lives of disadvantaged and marginalised individuals and communities. Participation refers to the central involvement of community members in all possible stages of research and associated change processes (Pain 2004; Kesby et al. 2005). PAR affirms the 'right and ability' of the 'researched' to have a say in decisions which affect their lives (Reason and Bradbury 2006: 10) and involves working with them to achieve the 'change that they desire' (Kindon 2005:208). It has been promoted as a beneficial approach when conducting research on children and young people’s lives, precisely because traditional research methods have often denied them the right to 'speak for themselves' (Qvortrup 1994:2). Over the past two decades numerous researchers have argued that children and young people must be brought into research as they have 'expert knowledge' of their lives (Robson 2001; Kellett et al. 2004:331). The assumption that adults always know what is in children’s best interests has been thoroughly disputed and disrupted (Jones 2001). Efforts to bring children and young people into research projects raise a number of ethical issues, particularly when the topic under investigation is a sensitive one (Robson 2001; Alderson and Morrow 2011). There is no one-size-fits all approach to determining when and how children and young people should become involved in research projects. However, many recent discussions of the ethics of involving children and young people in research have erred on the side of adjusting research procedures to minimise the potential for harm, rather than excluding children and young people from research in order to protect them (Matthews et al. 1998; Robson 2001; Porter et al. 2010; Alderson and Morrow 2011). 
PAR - whether undertaken with adults or children - is also a response to calls for 'more moral, caring and politically aware’ human geographies (Pain 2003:650). It can be particularly appealing for researchers whose work engages with traumatic issues and traumatised people because it promises to give something back. Human geographers are ‘socialised to be concerned' but typically have little to offer informants in return for their willingness to divulge distressing personal narratives (Woodby et al. 2011:835). PAR promises to make research encounters 'worth the tears' (Robson 2001) because it seeks to actively address the circumstances of participants' trauma. It eases the guilt that many researchers have expressed about extracting traumatic data without offering anything tangible in return (Widdowfield 2000; Meth and Malaza 2003; Woodby et al. 2011; Lund 2012).

My own involvement with PAR began during a research project with Tanzanian child domestic workers (Klocker 2011, 2012, 2014). In Tanzania, child domestic workers are predominantly female. They are girls who 'work in other people's households doing domestic chores, caring for children, and running errands’ (UNICEF 1999: 2). They work for pay in cash (or kind), are 'employed' by adults who are not their parents and usually live in their employers' homes (Kifle 2002). Child domestic work is a survival strategy. It is also ubiquitous: all but the poorest households have child domestic workers. Because child domestic work is carried out in unregulated domestic spaces, the living and working conditions of the young employees are largely at the whim of their employers. Traumatic experiences of abuse, exploitation, humiliation and isolation have been documented in numerous national contexts (Camacho 1999, Kifle 2002, Jacquemin 2004, Rubenson et al. 2004; Klocker 2011, 2014; Blagbrough 2008, Bourdillon 2009, Wasiuzzaman and Wells 2010). Yet attempts to abolish child domestic work in order to protect working children are problematic because the children involved typically have few alternatives (Klocker 2011, 
2014). I turned to PAR when researching child domestic work because I was aware of these complex and sensitive circumstances. I wanted to avoid investigating other people’s pain for the sake of knowledge alone; but as a white, middle-class, western researcher I could not know what Tanzanian girls needed. PAR offered an opportunity to work towards culturally sensitive and locally-relevant action and (in the process) to assuage my academic guilt. Or so it seemed.

In this paper I consider the following: traumatic research topics may induce researchers to adopt PAR without a clear understanding of the distressing outcomes that may unfurl as a direct result of this methodological choice. Here, I reflect on the emotional complexities and challenges of a PAR project - conducted on a traumatic issue and with traumatised young people - through a series of research vignettes. These bring together excerpts from interviews and my field diary to reveal the immediacy and emotional tensions of this research project 'in their rawest form' (Humble 2012:82; Punch 2012). They detail elements of PAR for which I was ill-prepared, and which became a source of (researcher, co-researcher and participant) distress in their own right. Emotion affected this research at every level and permeates this paper. The centrality of emotion to research has long been noted by feminist geographers (England 1994, Gibson-Graham 1994, Bondi 2005). Emotions flow through research relationships, practices and contexts (Laurier and Parr 2000; Widdowfield 2000; Meth and Malaza 2003; Bondi 2003, 2005; Bennett 2004; Punch 2012); they inform research methods, data collection, data analysis and research findings. The emotions experienced by researchers and research participants add meaning to research, they are 'as real, as important and as interesting as any other product of the interview' (Collins 1998:335; see also Lee-Treweek 2000; Bennett 2004; Humble 2012; Punch 2012). While all research is 'predicated on and in some ways involves - emotion’ (Askins 2009:8), this is perhaps most evident when traumatic 
issues are being investigated. As noted by the authors throughout this special issue, both researchers and participants may struggle to cope with the strain of such research encounters (see also Dunn 1991; Johnson and Clarke 2003; Meth and Malaza 2003; Dickson-Swift et al. 2007, 2008; Jones and Ficklin 2012; Lund 2012). Emotions are also central to PAR - not least because they motivate researchers to do something in response to apparent injustices ${ }^{1}$. PAR makes no pretence of being detached or objective. Under such circumstances, attentiveness to emotions is paramount - both to minimise the potential for harm, and to account for emotions’ influence on research findings and action-oriented outcomes.

\section{The research project and team}

This paper reports on a participatory and action-oriented investigation into child domestic work conducted in Iringa, Tanzania, from 2005 to 2007. The research team incorporated three former child domestic workers as co-researchers. Faidha Mlossi, Vaileth Mvena and Amina Haule $^{2}$ were aged 17, 15 and 14 (respectively) at the commencement of the research. The research team also included two adult Tanzanian co-researchers: Esther John Malifedha and Paul Mbenna. Esther, Paul and I all had experience and training relevant to the project. Esther and I had previously been trained by, and volunteered for, a non-government organisation in Iringa Municipality. In 2003, we spent seven months living in rural villages surrounding Iringa. Our role was to work at local primary schools where we engaged students and the community in discussions of health and children's rights. It was during this time that I first learned of, and became concerned about, child domestic work. I heard numerous stories of girls who had left their villages to gain employment as child domestic workers only to return disappointed by their experiences. Some had returned HIV positive. I was thus emotionally

\footnotetext{
${ }^{1}$ Brown and Pickerill's (2009) excellent special issue on activism and emotional sustainability, published in this journal, provides a useful overview of the role of emotions in compelling and sustaining researchers as activists. ${ }^{2}$ Amina Haule is a pseudonym. The other young researchers opted to be referred to using their real names in publications resulting from this work.
} 
connected to this issue and to this place before commencing my $\mathrm{PhD}$ research. Paul and I both attended an intensive and accredited two-week children's rights advocacy course in Tanzania in early 2005 (before starting fieldwork). During that time I refined the research project based on advice from Tanzanian children's rights experts. The young co-researchers were recruited as a result of their involvement with a local non-government organisation (NGO) engaged in advocacy efforts around child domestic workers' rights. These coresearchers had left child domestic work as a result of their own negative experiences and had developed skills in discussing these issues with other girls and young women through their involvement in that NGO's activities. After being recruited, the young co-researchers received research training from the adult members of the research team over a number of months. This training covered research methods and design (including interview skills), risk assessment and safety procedures, and ethical issues related to informed consent, discussing sensitive issues and confidentiality. The co-researchers were paid for their work. Faidha, Vaileth and Amina were engaged in all stages of the research process: they helped to set the project aims, they collected data and used this information to lobby for change. Data were collected from June 2005 to October 2006 via 30 interviews with current child domestic workers and 34 interviews with former child domestic workers; 25 personal narratives written by former child domestic workers; 57 interviews with employers of child domestic workers; and four focus group discussions with 29 local government leaders.

All data were collected in Kiswahili. Initially, a peer-interviewing model was adopted: the young co-researchers went in pairs to conduct interviews with current and former child domestic workers. The absence of adult team members from these interviews was a deliberate strategy to put the young interviewees at ease (Kellett et al. 2004). For reasons discussed later in this paper, this approach was soon abandoned and one adult always accompanied the 
young co-researchers for subsequent interviews with current and former child domestic workers. Interviews with adult employers of child domestic workers were always conducted by an adult/child pair in order to ensure the young co-researchers' physical safety. As the only non-Tanzanian member of the research team, I did not personally participate in interviews because the research team was concerned that my ‘foreign’ presence would prevent interviewees from discussing their experiences of child domestic work openly. This adds a layer of complexity when discussing my experiences of traumatic research content in this paper: I was responsible for a team of researchers who came into direct contact with traumatised people and traumatic narratives but my own involvement was at arms' length. I came into contact with the research data during debriefing sessions with other team members after interviews, and as I translated Esther's transcripts from Kiswahili into English.

At the outset of our research collaboration, the young co-researchers were adamant that this research project should be action-oriented: it should aim to improve child domestic workers' lives. They suggested we use the research to develop an employment contract to regulate and formalise child domestic work in Iringa Municipality. Interviews and focus groups discussions were used to determine whether this suggestion had broader support (see Klocker 2011). After determining that there was a high level of stakeholder support for the regulation of child domestic work in Iringa, repeated stakeholder forums and project team meetings occurred to prepare the content of a draft employment contract and supporting by-law. These documents were submitted to the Iringa Municipal Council for consideration in 2007. Unfortunately, although key local government officials - including the Mayor - had conveyed support for the project from its commencement, the Council declined to deliberate on the proposed by-law unless financial 'incentives' were provided. Ethical concerns and financial limitations prevented the research team from providing such incentives, thus our 
efforts at engendering change were halted. The political will to enact change was lacking (see Pain and Francis 2003). After many months of data collection and analysis, advocacy and lobbying efforts the research team had to concede that the contract and by-law (and thus our PAR project) had failed to achieve its overarching objective of improving the employment conditions of child domestic workers. This is not to say that this project did not have any positive outcomes: the research team developed and presented a weekly local radio programme that discussed and advocated for children's rights and participated in community seminars and events designed to raise awareness of child domestic work. Further, the young co-researchers undoubtedly benefited from the income they were able to earn through the project - which was used to invest in further education and training to improve their employment prospects. The young co-researchers were also engaged in a number of project evaluation activities in which they reported that participation in the project had improved their confidence and self-esteem, and had made them feel more capable. Nonetheless, my focus in this paper is on the enduring disappointment of not succeeding in implementing structural changes that would benefit child domestic workers over the longer-term.

\section{A note on terminology}

Several of the children and young people who were interviewed had survived immense trauma as child domestic workers. Members of the research team regularly and repeatedly received, heard, read and analysed heart-wrenching stories of physical, sexual and verbal abuse and harassment, of isolation, loneliness and neglect, and of economic exploitation (see Klocker 2011, 2012, 2014 for further discussion of the evidence collected in relation to child domestic workers' experiences of their occupation). This was a harrowing research topic. There were many days when it all felt too difficult: I cried about this project, I got angry, I had nightmares, I experienced anxiety attacks and heart palpitations, sleepless nights and - as 
a PhD student and novice researcher - an overwhelming sense of being utterly out of my depth. I experienced a ‘maelstrom of emotions’ (Brown and Pickerill 2009:25). But in writing this paper, I cannot use the term 'trauma' to describe my own experiences as a researcher. Unlike Dunn (1991:389), I do not feel comfortable asserting that there were 'parallels' between my physical and emotional responses as a researcher and those of the research participants. Trauma - as 'emotional shock following a stressful event... which may lead to long-term neurosis’ (Oxford English Dictionary) - accurately defines the experiences of child domestic workers (including my young co-researchers) who have been beaten, raped, sexually harassed, locked up, overworked, denied humanity, ridiculed and belittled, isolated from friends and family and denied wages. There is no equivalence between my experience of conducting research on child domestic work and their experience of doing child domestic work. Throughout this paper, I refer to my own experiences in terms of researcher distress (rather than trauma) in acknowledgement of the incomparability of our experiences.

\section{Unpacking the emotional complexities of PAR}

In the remainder of this paper, I discuss three aspects of PAR for which I was inadequately prepared. These became sources of (researcher, co-researcher and participant) distress in their own right. First, PAR projects potentially expose a constellation of participatory coresearchers to traumatic narratives. The academic researcher is responsible for the emotional wellbeing of a research team. Second, contributing to change is messy. For action-oriented researchers, the possibility of contributing to structural changes (with potentially widereaching and long-lasting implications) can be both alluring and intimidating. There is no guarantee that the impacts of PAR projects will be unambiguously positive and, in some instances, change processes may generate more harm than good. This responsibility can weigh heavily on the minds of the research team. Third, PAR projects often fail to make a 
difference, to live up to their own lofty ambitions. Failing to make the types of differences that seem sufficiently 'big' and 'important' is deeply distressing. These feelings are compounded when the research team is left feeling that they have failed to improve the circumstances of traumatised people - in our case, child domestic workers.

\section{PAR: Spreading the 'rights' and 'burdens' of research}

PAR extends the 'right' to participate in research projects to non-academics by insisting that affected communities and individuals be involved in all possible stages of the research process and associated outcomes. But with rights come burdens. When PAR is conducted on traumatic issues, the emotional burdens of the research are spread across a research team. This issue became apparent during several moments in our collective project on child domestic work. The first example relates to Esther, who repeatedly listened to and transcribed traumatic audio recordings of interviews. This process took an emotional toll, as noted in my field diary:

Esther started transcribing and the two that she has finished so far are horror stories... One [interviewee] started child domestic work when she was 8 and quit at the age of 12 because she was pregnant. The other was raped by her employer's son... Esther was so deeply into the transcribing...She didn’t even stop for lunch because she wanted to know “what happens”. But every so often she stood up and said, "I can’t listen anymore”, and had to take a few minutes away because she had just hit an emotional part (Field Diary, 16.3.06).

Repeated listening to traumatic narratives - in an attempt to produce an accurate transcription - can be harrowing. Transcribers are ‘drawn into the lives of research participants’ (Gregory 
et al. 1997: 294), even when they have never met. When the transcriber has not had direct contact with an interviewee, they may compensate by 'supplementing details of the original encounter through imagination' - this imagination 'may conceive a reality more powerful and disturbing than what was originally recorded on tape' (Gregory et al. 1997:296). Thus being at arms' length from traumatised research participants does not always offer relief (Fincham et al. 2008). I did not have to witness interviewees’ tears firsthand, but I nonetheless found the research data deeply distressing. I found myself trying to fill in the gaps in my knowledge by asking my co-researchers to share their insights with me: What was the house like? Did the girl seem ok? Did she cry? How hard did she cry? Did she look healthy? Do you think she is being harmed where she currently works? Do you think we need to do something to get her out of her present situation? ${ }^{3}$

A second example of the distributed emotional burden of PAR relates to the young coresearchers themselves. As noted previously, the peer-interviewing model adopted in this project was premised on a belief that the young co-researchers and young interviewees' shared experiences of child domestic work would make for empathetic and open interview encounters. Peer-interviewing is supposed to enable 'closer intimacy and fuller discussion' (Alderson 2001:141). Yet in this project, the young co-researchers appeared to be at a loss when faced with traumatic stories during interviews. This became apparent as Esther and I prepared the transcripts and translations of two early peer interviews conducted by the young co-researchers. The relevant sections of text are presented below:

\footnotetext{
${ }^{3}$ It is worth noting here that none of the current child domestic workers who were interviewed told of traumatic experiences in the homes where they were employed at the time of interview. All traumatic narratives referred to prior experiences from which they had extricated themselves. The possible reasons for this have been discussed in Klocker (2012).
} 
Former child domestic worker: The male child [son of the employer]...he raped me, I went to tell my mother.

(All of them stayed quiet for a moment).

Amina: Mmm, what action did your mother take?

Former child domestic worker: She told me I should leave work.

Amina: In your opinion, what should be done so child domestic workers do not experience problems?

Faidha: What caused you to leave home and go to work?

Former child domestic worker: My grandfather was beating me a lot. One day he prepared hot water so that he could bathe, he poured it on me, I was burnt... I decided to leave and to go to work [as a domestic worker]...I did not want to go back to my grandfather again because I knew he could kill me...

Faidha and Vaileth: Ok, ok.

Vaileth: Is there any person who convinced you to do domestic work?

Esther and I were deeply distressed when we listened to these recordings - not only because of the nature of the experiences being recounted, but also because of the apparent lack of empathy displayed in the moment of the research encounter by the young co-researchers. We were concerned to address this issue, not least because of the potential for such a 'clinical' approach to further traumatise the young interviewees in the retelling of their horrific experiences ${ }^{4}$. We invited Vaileth, Amina and Faidha to tell us what they found challenging about conducting interviews on this upsetting topic, but they did not express any emotional discomfort. At the time, I interpreted this situation as an indication that they considered

\footnotetext{
${ }^{4}$ Esther visited the young interviewees behind these stories to check that they were alright after these interviews and to offer access to support services if needed.
} 
research to be a formal activity, and had thus attempted to leave their normal emotional responses out of it. In hindsight, it seems clear that this research project asked a lot of these young co-researchers - perhaps too much. Our research design initially prioritised a 'pure' interpretation of participation according to which the adult researchers attempted to be as hands-off as possible. In so doing, it gave insufficient attention to the implications of this approach for the young co-researchers themselves, as they listened to traumatic narratives stories which likely raised memories of their own traumatic experiences of child domestic work. Their awkward silences during interviews, their rush to move onto the next question when sensitive issues were being discussed, and their unwillingness (or inability) to communicate these issues with the adult researchers during debriefing sessions, all suggest that this PAR project may have pushed them too far. This example serves as an important reminder that ethics and emotion are intertwined in research (Dickson-Swift et al. 2008). Researchers are not just potential “creators’ of situations of distress, but also...active participants who are also distressed through the research process’ (Meth and Malaza 2003:150).

We responded to abovementioned issue by changing our research approach, an adult researcher was present in all subsequent interviews conducted by the young co-researchers. The intent here was two-fold: first, to ensure that interviewee distress was dealt with appropriately during and after the research encounter, and second to ensure that de-briefing discussions could be held with the young co-researchers immediately after interviews had taken place. We were able to respond to the abovementioned situation quickly, precisely because we carefully monitored the interview recordings within a day or two of the interviews occurring. There were undoubtedly elements of our initial research approach that were flawed - perhaps even reckless (despite the fact that the project design had been 
subjected to formal scrutiny by the relevant university ethics committee and the Tanzania Commission for Science and Technology (COSTECH), and had been discussed with a number of Tanzanian children's rights experts). Fortunately we were able to respond to minimise harm quickly due to our monitoring procedures. Dickson-Swift et al. (2008:135) have asked:

How can we be sure that those whom we send out to do interviews on sensitive topics have any minimum level of competence in dealing with research participants who may be undergoing significant emotional reactions during the research? We cannot.

I agree wholeheartedly: we cannot be sure. But we can ensure that close scrutiny of research activities is a routine part of participatory research projects involving novice co-researchers. Strategies for quickly identifying unacceptable emotional burdens (for researchers and interviewees) ought to be built into participatory research designs.

The abovementioned scenario also raises deeper and important questions about what constitutes an appropriate level of participation in sensitive research projects, particularly when they involve children. In the context of PAR, it is important to ask: are there some circumstances under which the 'right' to participation constitutes an inappropriate (and ultimately traumatic) burden? Interestingly, the adult members of the research team felt guilty about asserting greater control over the project in response to this situation. We felt that having an adult accompany the young co-researchers on all interviews represented a retreat from what we (at the time) considered an ideal form of participation. We felt that we were selling out. But this feeling was based on a very particular view of participatory research one derived from Chambers' (1997) model of 'handing over the stick' according to which 
participation ideally involves relinquishing control. Letting go of these ideals can be difficult when confronted by a PAR literature that can sometimes come across as judgemental of ‘diluted’ participatory endeavours (see Klocker 2012). Melton (2000) has instead promoted collaborative interpretations of participation that bring adults and children together rather than promoting the absolute independence of the latter. Collaborative interpretations of participation also have clear ethical benefits in terms of minimising the risk of harm to young co-researchers and interviewees. As shown clearly in this paper, taking a hands-off approach can be harmful, unethical even. It is important that participatory researchers be flexible rather than purist in their understandings of what constitutes the most appropriate level of participation in a project (Kesby et al. 2005) - particularly when sensitive issues and children are involved.

PAR: coping with making a difference

As a research team, we commenced this PAR project with the knowledge that it may fail to make a difference to the lives of child domestic workers. This issue is discussed in the following sub-section. However, there were times throughout the project when change seemed possible, even imminent. This raised a set of questions that I had failed to consider before embarking on this project: Were we truly prepared for the ramifications of making a difference? Were we prepared for the cascading effects that might eventuate from our attempts to intervene in traumatised people's lives?

I began to feel a great deal of anxiety as the research team - together with community stakeholders - began the process of drafting the employment contract and supporting by-law intended to regulate the living and working conditions of child domestic workers in Iringa Municipality (see Klocker 2011 for the content of these documents). Setting an appropriate 
minimum age for child domestic work was a particularly delicate issue. Most of the interviewees and community stakeholders - including current and former child domestic workers themselves - argued that the proposed contract should specify a minimum age of 15 years for employment. This minimum age was actually above that set in the Tanzanian Employment and Labour Relations Act 2004 which (in line with the 1989 United Nations Convention on the Rights of the Child and the 1999 ILO Convention on the Worst Forms of Child Labour) prohibits all work for children under 14 years of age, and all but 'light work' for children between 14 and 15 years of age. The desire expressed by the working children involved in this study to set a minimum age for employment stood in marked contrast to Bourdillon's (2009) observation that child workers generally do not support minimum age standards as they affect their ability to support themselves and ensure their survival in contexts of poverty (see also Woodhead 1999). The strict application of minimum age standards may result in greater harm, pushing children into more precarious occupations in the struggle to survive (Woodhead 1999; Abebe 2008; Bromley and Mackie 2009). I became concerned: if the minimum age of 15 were enforced in Iringa Municipality, the implications for younger girls (with no alternative means of financial support) could be disastrous. But I was part of a team and - by virtue of the participatory process - I felt it was inappropriate to impose my own will. The preferences of the overwhelming majority of the research team members, interviewees and community stakeholders was to set a minimum age of 15 years and this decision prevailed.

Researchers have an ethical responsibility to 'avoid negative consequences both for the people studied and for others' (Cloke et al. 2000:135). The realisation that our efforts to instigate change would (if successful) actually affect real people's lives filled me with a great deal of trepidation: 
I got into a sudden panic yesterday. What if we successfully implement a contract system and then employers punish their child domestic workers for making a report to the street chairperson ${ }^{5}$ ? What if a child gets beaten up because of this research? What if a child loses her job and becomes homeless?...Paul said I shouldn’t worry so much because they are already being beaten up now and the number who will suffer will surely decrease not increase. But...where does my (and the research team’s) responsibility end? (Field Diary, 6.2.06)

I found the responsibilities associated with PAR intimidating. The learning curve on this project was steep and the 'stakes' were high, as real people’s lives were involved (Kindon and Elwood, 2009: 24). In hindsight, I was ill-prepared for that eventuality. Researchers attempting PAR must take the time to pause and to ask themselves (and other members of their research teams) whether they are ready for the potential consequences of the actions for which they are advocating. I was not prepared. I felt out of my depth and profoundly anxious. As a result of these concerns, I had mixed feelings (immense disappointment alongside considerable relief) when the research team's efforts to implement our draft regulatory instruments ultimately stalled.

\section{PAR: coping with not making a difference}

When conducting research on a traumatic issue, there is a great deal of pressure to achieve something. The traumatic narratives that we were all exposed to during this project on child domestic work seemed 'worth' the pain; as long as they were contributing to a process of

\footnotetext{
${ }^{5}$ Street chairpeople are elected local government representatives who live on the 'street' for which they are responsible (usually several streets, but a small enough area for them to be very familiar with the other residents). A number of street chairpeople in Iringa were heavily involved in our research project and were pivotal to the monitoring system that was proposed as part of the draft contract and by-law. They were written into these instruments as the first point of contact if a person was acting in violation of the proposed regulations.
} 
change. Yet for academics who engage in PAR with the hope of achieving wide-reaching and structural reforms, 'failure' is a realistic prospect. Our efforts to regulate child domestic work did not end successfully. When a deeply emotional research process is premised upon 'making a difference' apparent failure is hard to accept, and can become a source of great distress in its own right. Although this project did have other positive outcomes (as noted earlier in this paper), in our minds these did little to overcome the disappointment of not succeeding in implementing lasting structural changes. The pressure and sense of responsibility already felt by members of the research team mounted when child domestic workers who were interviewed commented:

I am very grateful [for the research team’s work], and after seeing that contract [in force] I will follow you by hook and by crook to come to thank you.

I just say 'thank you' because there are some girls, they are harassed...if you do this [bring in a contract] they will feel good and those who are not paid will start to be paid.

At one point, Vaileth told me that child domestic workers were willing - even happy - to be interviewed because ‘they know that we will help them’ (Field Diary 13.6.06). An employee at a local shelter for child domestic workers noted: 'this idea of yours is very good, if it will succeed to pass [Council] it will help these children a lot' (Field Diary, 21.6.06). Some of the employers interviewed drew attention to the failure of other initiatives and researchers to implement change in their community, and we felt desperate not to fall into that category: 
Perhaps I should ask you... will it be implemented?...Because often issues like these...[researchers] pass by but we don't see implementation...I will be grateful if you will follow up these issues and put them right...

I thank you very much for coming to our place here. I think if you have really decided to do this, well, God should fill you with strength so that you will be able to follow this up.

In order to manage our interviewees' expectations, and those of the young co-researchers, we openly explained that the success of our PAR project was dependent upon the Council's willingness to engage with our draft regulatory instruments. But this did not diminish the weight of expectation that we felt. The final outcome of our project depended upon the willingness of 'more powerful individuals or organisations to acknowledge the need for change' (Pain and Francis 2003:52) and this was not forthcoming:

It feels so hopeless. Paul and I went to meet with a Labour Officer at the Regional Administration building this morning. He focuses on child labour. We told him what we are trying to do and his first reaction was to laugh...Sometimes I just want to give up because we have created something [a draft contract], with the community, that is designed to meet their needs in a realistic manner, yet the government doesn't want to talk about reality...Arrrrggggghhhhhh!!....He [the labour officer] said to me, "Don’t worry, you will have a great PhD”...[but] I'm not worried about my PhD (Field Diary, 13.10.06). 
With PAR, there will not always be a "successful' change effort to document with a happy ending’ (Herr and Anderson, 2005: 128). Indeed, ‘fulfilling the key premise of participatory research - effecting change with participants - is fraught with difficulties' (Pain and Francis 2003:52). This is the 'reality of participatory practice versus its sometimes glossy (or glossedover) presentation’ (Pain, 2004: 658). Maguire (1987:42), whose own PAR project with battered women did not turn out as she had hoped ('no revolution resulted'), emphasised the importance of celebrating any attempt to achieve meaningful and appropriate social change, 'no matter how flawed, small-scale or less than ideal' it turns out to be (Maguire 1987:176). Feelings of inadequacy and burnout are common among activist researchers (Brown and Pickerill 2009). It is thus crucial to 'nurture ourselves' (and our co-researchers) 'as we move, however slowly and imperceptibly, in the direction of change for social justice' (Maguire 1987:199). Despite these reassuring words - and my mixed emotions (was I relieved or devastated that we had failed?) - our inability to achieve structural and long-lasting change through this PAR project had real implications for child domestic workers. I did a poor job of managing my 'feelings of guilt and hopelessness' at failing to redress 'injustice and malpractices’ (Lund 2012:95). In the concluding section of this paper I consider what the various emotions that flowed through this PAR project (and the various relationships entailed therein) reveal about research design, participatory and action-oriented research methods, and indeed about the topic of child domestic work itself.

\section{Concluding remarks}

Emotions affected this research project at every level - from its very inception. In the first instance, my emotional response to the traumatic circumstances of child domestic work prompted me to adopt PAR as a research methodology. But I found that PAR was not a panacea - rather, it created a number of distressing scenarios for which I was poorly 
prepared. My reflections throughout this paper highlight a clear gap in university ethics procedures and support structures for researchers undertaking PAR - particularly in relation to sensitive or traumatic topics. A broader interpretation of the 'do no harm' principle is particularly pertinent and urgent in relation to PAR projects that involve inexperienced coresearchers who may be ill-equipped to deal with traumatic research encounters. The manner in which harm is interpreted should perhaps be expanded to incorporate researchers (both academic and community co-researchers) in its remit. My ethics application explicitly stated that I planned to work with young co-researchers who were themselves former child domestic workers. This was presented as a deliberate strategy to minimise the risk of harm and discomfort amongst child domestic workers interviewed throughout the study. Upon reflection, this approach essentially positioned my young co-researchers as a means to an (ethical) end, rather than a group to whom an ethical duty of care should be explicitly extended. This duty of care needs to be made clear in ethics protocols as the risk of harming co-researchers in participatory projects (particularly when these projects relate to traumatic issues) is profound. Preventing such harm ought to be a priority.

Second, the ethical principle of avoiding harm does not account for the complex emotions involved in projects that seek to make a difference. I went into this project well aware that it might fail to achieve its action-oriented objectives. Such failure has been discussed by a number of PAR practitioners (Maguire 1987; Herr and Anderson, 2005; Pain and Francis 2003; Pain, 2004). However, I have not come across another study that has articulated the panic that I experienced when I realised that this project might actually succeed in making a difference. Given the complex nature of social justice issues, this is a surprising absence. I am sure I am not the first researcher to have felt this way. Change is a messy process and any attempts to improve people's life circumstances - even through thorough and engaged PAR 
processes - may lead to an array spin-off effects that are difficult to predict. In some cases, change efforts may generate more harm than good, they may compound trauma and disadvantage rather than redressing it. This caution is not intended to deter others from attempting to achieve positive social change. But I do hope that this paper will prompt greater recognition of the profound responsibility of research efforts that seek to tangibly intervene in traumatised people’s lives. Researchers engaged in PAR need to look well beyond the immediate and direct forms of harm that may be associated with their work.

In making these assertions I am not seeking to avoid responsibility for the aspects of my PAR project that were ill-conceived. If I were to have my time over again, there are many things I would have done differently. At the time, I felt that I had followed the correct procedures: I had immersed myself in the literature, I had sought the appropriate ethics approvals, I had engaged with Tanzanian experts on my research topic, and I had recruited a participatory research team that was well-equipped to work on this issue. But some things still did not go according to plan, and a number of events took me (us) by surprise. In hindsight, there was an important omission in my approach. I should have submitted my research methodology to peer-review by academics with specific expertise in conducting PAR with traumatised people and on sensitive issues. They would have been well-equipped to forewarn me about the risks of my approach; and this paper is my attempt to do so for others who may be attempting PAR for the first time.

In closing, a number of researchers have drawn attention to the significance of emotions for gaining a deeper understanding into the research topic under investigation. Reflexive engagements with emotion 'can lead to insights that are not only particularly revealing about the research process and the motivations of the researcher, but are also highly informative 
about the subject area' (Humble 2012:78). The emotions that 'mediate fieldwork (through both the researcher and the researched)' provide 'clues' that help researchers 'to decipher the social worlds of those they study' (Bennett 2004:146). Being honest and open about these emotions is crucial - indeed, 'ignoring or repressing feelings about research is more likely to produce distortion of data, rather than clarity’ (Lee-Treweek 2000:128). By thoroughly interrogating my conflicting emotions about the action-oriented outcomes of this project, I learned a great deal about the complexity of child domestic work. Was I anxious or excited about the potential to make a difference? Did I feel guilty, disappointed or relieved when our efforts to engender change faltered? In reality, I felt all of these contradictory things. At the same time. And in equal measure. My jumbled up emotions reflected the messy reality of child domestic work. Some children are abused and exploited by misanthropic employers. Others are treated reasonably - even with care - in their employers' homes. Many children are affected by devastating poverty and rely on child domestic work to survive. Some children are orphans, or come from abusive homes, and have nowhere else to turn. Child domestic work can offer relief. Equally, it can be traumatic beyond words. Attentiveness to my own conflicting emotions alerted me to the complexity of an employment scenario that defies simple categorisation and necessitates a nuanced response. 


\section{References}

Abebe, T. (2008) 'Earning a Living on the Margins: Begging, Street Work and the Sociospatial Experiences of Children in Addis Ababa', Geografiska Annaler, Series B 90 (3): 271284.

Alderson, P. (2001) 'Research by children', International Journal of Social Research Methodology, 4(2):139-153.

Alderson, P. and Morrow, V. (2011) The Ethics of Research with Children and Young People: A Practical Handbook, Sage, London.

Askins, K. (2009) 'That’s just what I do’: Placing emotion in academic activism’, Emotion, Space and Society, 2(1): 4-13.

Bennett, K. (2004) ‘Emotionally intelligent research’, Area 36(4): 414-422.

Blagbrough, J. (2008) ‘Child Domestic Labour: A Modern form of Slavery’ Children \& Society 22 (3): 179-190.

Bondi, L. (2003) 'Empathy and identification: conceptual resources for feminist fieldwork;, ACME: International Journal of Critical Geography, 2: 64-76.

Bondi, L. (2005) 'Making connections and thinking through emotions: between geography and psychotherapy', Transactions of the Institute of British Geographres, 30:433-448. Bourdillon, M. (2009) ‘Children as Domestic Employees: Problems and Promises’, Journal of Children and Poverty, 15 (1): 1-18.

Bromley, R., and Mackie, P. (2009) 'Child Experiences as Street Traders in Peru:

Contributing to a Reappraisal for Working Children', Children’s Geographies 7(2): 141-158.

Brown, G. and Pickerill, J. (2009) ‘Space for emotion in the spaces of activism’, Emotion, Space and Society, 2(1): 24-35.

Camacho, A. (1999) 'Family, Child Labour and Migration: Child Domestic Workers in Metro Manila’ Childhood 6 (1): 57-73. 
Chambers, R. (1997) Whose Reality Counts? Putting the First Last. ITDG Publishing: London.

Cloke, P., Cooke, P., Cursons, J., Milbourne, P. and Widdowfield, R. (2000) 'Ethics, reflexivity and research: encounters with homeless people', Ethics, Place and Environment, 3, 133-154.

Collins, P. (1998) 'Negotiating selves: Reflections on 'unstructured' interviewing', Sociological Research Online, Vol 3 (3):. www.socresonline.org.uk/socresonline/3/3/2/html, Accessed 28 September 2014

Dickson-Swift,V., James, E., Kippen, S. and Liamputtong, P. (2007) ‘Doing sensitive research: what challenges do qualitative researchers face?' Qualitative Research, 7(3): 327353.

Dickson-Swift,V., James, E., Kippen, S. and Liamputtong, P. (2008) 'Risk to researchers in qualitative research on sensitive topics: issues and strategies', Qualitative Health Research, 18(1): 133-144.

Dunn, L. (1991) ‘Research Alert! Research may be hazardous to your health!', Qualitative Health Research, 1(3): 388-392.

England, K. (1994) ‘Getting personal: reflexivity, positionality and feminist research’, The Professional Geographer, 46: 80-89.

Fincham, B., Scourfield, K. And Langer, S. (2008) 'The impact of working with disturbing secondary data: reading suicide files in a coroner's office', Qualitative Health Research, 18(6): 853-862.

Gibson-Graham, J-K (1994) “'Stuffed if I know!’ Reflections on post-modern feminist social research’, Gender, Place and Culture, 1:205-224.

Gregory, D., Russell, C. And Phillips, L. (1997) 'Beyond textual perfection: transcribers as vulnerable persons', Qualitative Health Research, 7(2): 294-300. 
Herr, K. and Anderson, G. (2005) The Action Research Dissertation: A Guide for Students and Faculty. Sage Publications: London.

Humble, D. (2012) “'This isn’t getting easier’: valuing emotion in development research’, Emotion, Space and Society, 5: 78-85.

Jacquemin, M. (2004) ‘Children’s Domestic Work in Abidjan, Cote D’Ivoire: The Petites Bonnes have the Floor' Childhood 11 (3): 383-397.

Johnson, B. and Clarke, J. (2003) ‘Collecting sensitive data: the impact on researchers’, Qualitative Health Research, 13(3): 421-434.

Jones, O. (2001) “'Before the Dark of Reason’: Some Ethical and Epistemological Considerations on the Otherness of Children', Ethics, Place and Environment, 4(2):173-178. Jones, B. and Ficklin, L. (2012) 'To walk in their shoes: recognising the expression of empathy as a research reality’, Emotion, Space and Society, 5:103-112.

Kellett M., Forrest, R., Dent, N. and Ward, S. (2004) 'Just Teach Us the Skills Please, We’ll Do The Rest: Empowering Ten-Year Olds as Active Researchers '. Children \& Society, 18: $329-343$.

Kesby, M., Kindon, S. \& Pain, R. (2005) Participatory research, in: R. Flowerdew (Ed.) Methods in Human Geography: A Guide for Students Doing a Research Project, 2nd edn, pp. 144-166 (London: Pearson).

Kifle, A (2002) Ethiopia. Child Domestic Workers in Addis Ababa. Geneva: ILO-IPEC. Kindon, S. (2005) Participatory action research, in: I. Hay (Ed.) Qualitative Research Methods in Human Geography, 2nd edn, pp. 207-220 (Melbourne: Oxford University Press). Kindon, S. \& Elwood, S. (2009) 'Introduction: More than methods - Reflections on participatory action research in geographic teaching, learning and research', Journal of Geography in Higher Education, 33: 19-32. 
Klocker, N. (2011) 'Negotiating change: working with children and their employers to transform child domestic work in Iringa, Tanzania’ Children’s Geographies, 9(2): 205-220. Klocker, N. (2012) 'Conducting sensitive research in the present and past tense: recounting the stories of current and former child domestic workers’ Geoforum, 43(5): 894-904. Klocker, N. (2014) 'Struggling with child domestic work: what can a postcolonial perspective offer?’ Children’s Geographies, 12(4): 464-478.

Laurier, E. and Parr, H. (2000) 'Emotions and interviewing in health and disability research', Ethics, Place and Environment, 3:98-102.

Lee-Treweek, G. (2000) 'The insight of emotional danger: Research experience in a home for older people’, In: Lee-Treweek, Geraldine, Linkogle, Stephanie (Eds.), Danger in the Field: Risk and Ethics in Social Research. Routledge, London.

Lund, R. (2012) 'Researching crisis - recognising the unsettling experience of emotions', Emotion, Space and Society, 5: 94-102.

Matthews, H., Limb, M. and Taylor, M. (1998) 'The Geography of Children: some ethical and methodological considerations for project and dissertation work', Journal of Geography in Higher Education, 22(3): 311 - 324

Maguire, P. (1987) Doing Participatory research: a feminist approach. Centre for International Education, University of Massachusetts: Amherst, MA.

Melton, G. (2000) ‘Parents and children: legal reform to facilitate children's participation', in Smith et. al. (Eds) Advocating for Children: International Perspectives on Children's Rights. Children's Issues Centre, University of Otago Press: Dunedin, New Zealand, pp. $141-158$.

Meth, P. and Malaza, K. (2003) 'Violent research: the ethics and emotions of doing research with women in South Africa', Ethics, Place and Environment, 6(2): 143-159. Pain, R. (2003) ‘Social geography: on action-oriented research’. Progress in Human 
Geography, 27(5): $649-657$.

Pain, R. and Francis, P. (2003) 'Reflections on Participatory Research’. Area, 35(1): 46 54.

Pain, R. (2004) ‘Social geography: participatory research’. Progress in Human Geography, 28(5): 652-663.

Porter, G., Hampshire, K., Bourdillon, M., Robson, E., Munthali, A., Abane, A., Mashiri, M. (2010) 'Children as research collaborators: issues and reflections from a mobility study in sub-Saharan Africa’, American Journal of Community Psychology, 46: 215-227.

Punch, S. (2012) 'Hidden struggles of fieldwork: exploring the role and use of field diaries', Emotion, Space and Society, 5: 96-93.

Qvortrup, J. (1994) ‘Childhood Matters: An Introduction’ in Qvortrup, J. et. al. (Eds) Childhood Matters: Social Theory, Practice and Politics. Avebury Press: Aldershot, UK, pp. $1-23$

Reason, P. and Bradbury, H. (2006) (Eds) Handbook of Action Research. Sage Publications: London.

Robson, E. (2001) 'Interviews Worth the Tears? Exploring Dilemmas of Research with Rubenson, B., N. Anh, B. Hojer, and E. Johansson (2004), 'Child Domestic Servants in Hanoi: Who Are They and How Do They Fare?' International Journal of Children's Rights 11 (4): 391-407.

UNICEF. 1999. Innocenti Digest: Child Domestic Work. Florence: UNICEF.

Wasiuzzaman, S., and K. Wells (2010) 'Assembling Webs of Support: Child Domestic Workers in India', Children \& Society 24 (4): 282-292.

Widdowfield , R. (2000) 'The place of emotions in academic research', Area, 32:199-208. 
Woodby, L., Williams, B., Wittich, A. and Burgio, K. (2011) 'Expanding the notion of researcher distress: the cumulative effects of coding', Qualitative Health Research, 21(6): 830-838.

Woodhead, M. (1999) 'Combatting Child Labour: Listen to What the Children Say’, Childhood 6 (1): 27-49. 